\title{
Field-scale in situ measurements of vadose zone flow and transport using multiple tracers at INEEL Vadose Zone Research Park (VZRP) - EMSP5-02-06
}

\author{
Annual Report June 30, 2004 \\ Lawrence Hull, PI, Idaho National Engineering and Environmental Laboratory
}

\section{Research Objective}

This study is aimed at obtaining a better understanding of vadose zone flow and transport processes at the field scale and establishing defensible links between laboratory- and fieldderived transport parameters for conservative and reactive elements in the vadose zone. The study site (Vadose Zone Research Park [VZRP] at INEEL) provides a three-dimensional instrumentation array strategically surrounding new infiltration ponds, and the Big Lost River, and intermittent stream proximal to the infiltration ponds. The proposed research will utilize the infiltration ponds and the Big Lost River to study the effects of fluid flux, water chemistry and degree of saturation on contaminant transport in the vadose zone. Our research plan has four major objectives: 1) evaluate the transport of conservative and reactive solute and colloid tracers through the vadose zone and local perched water zones; 2) examine isotopic variations of $U$ and Sr and compare these to introduced sorbing and non-sorbing tracers; 3) develop and calibrate a conceptual flow and transport model, and 4) examine the effects of flow and geochemical transients on tracer and colloid transport.

\section{Research Progress and Implications}

As of June 25, 2004 this report summarizes the work after about 21 months of a 3-year project. Three major tests were conducted during 2002 and 2003:

1. Background chemistries were collected for water residing in the vadose zone prior to initial filling of the infiltration ponds

2. Initial filling of infiltration ponds: Approximately 200 samples were collected during this “initial wetting” event. Most have been analyzed for major anions and cations. A subset has also been analyzed for $\mathrm{H}, \mathrm{O}, \mathrm{Sr}$ and $\mathrm{U}$ isotopics.

3. Test 1: Conducted during "steady state" flow into south pond during June and July 2003. Test consisted of injection of $\sim 19 \mathrm{~kg}$ of 2,4,5- tFBA and subsequent collection over next month of $>1200$ samples from monitoring wells and lysimeters. Tracer analyses are ongoing.

4. Test 2: Conducted in the north pond and coincided with planned switch of discharge water from the south pond. Injection of tracer was coincident with wetting of north pond, which had been dry for about 1 year. Tracer consisted of $\sim 25 \mathrm{~kg}$ of $\mathrm{KBr}$ and $\sim 21 \mathrm{~kg}$ of 2,4,-dFBA injected simultaneously. Over 3000 samples were collected over next two months. Analyses for Br tracer are complete. Tracer recovery curves are presented in figure 1. Samples were also collected for determination of colloid concentrations and particle size determination. A subset of samples have been analysed for ${ }^{234} \mathrm{U} /{ }^{238} \mathrm{U}$ and ${ }^{87} \mathrm{SR} /{ }^{86} \mathrm{Sr}$ isotope analyses. These data show that $\mathrm{U}$ and $\mathrm{Sr}$ isotope ratios and concentration have changed during the course of the tests and therefore they should be of value in fingerprinting sources of these constituents during reactive transport.

5. Sorption batch test were conducted on the 2,4,-dFBA used for the 2003 tracer studies. Given the assumptions that the FBA's are conservative it was important to demonstrate 
that this was true in the geologic material of the ESRP surface alluvium. Results indicate that over the time period and concentration range utilized for the study the 2,4,-dFBA is indeed conservative. However, preliminary results indicate that over longer time periods and at higher concentrations the tracer may not be entirely conservative.

6. Additional Work: During 2003, core samples from the VZRP were described and samples were collected for laboratory characterization and transport tests. During June of 2004, water samples from 3 wells completed in perched water zones at different depths were collected for the purpose of characterizing natural colloids.

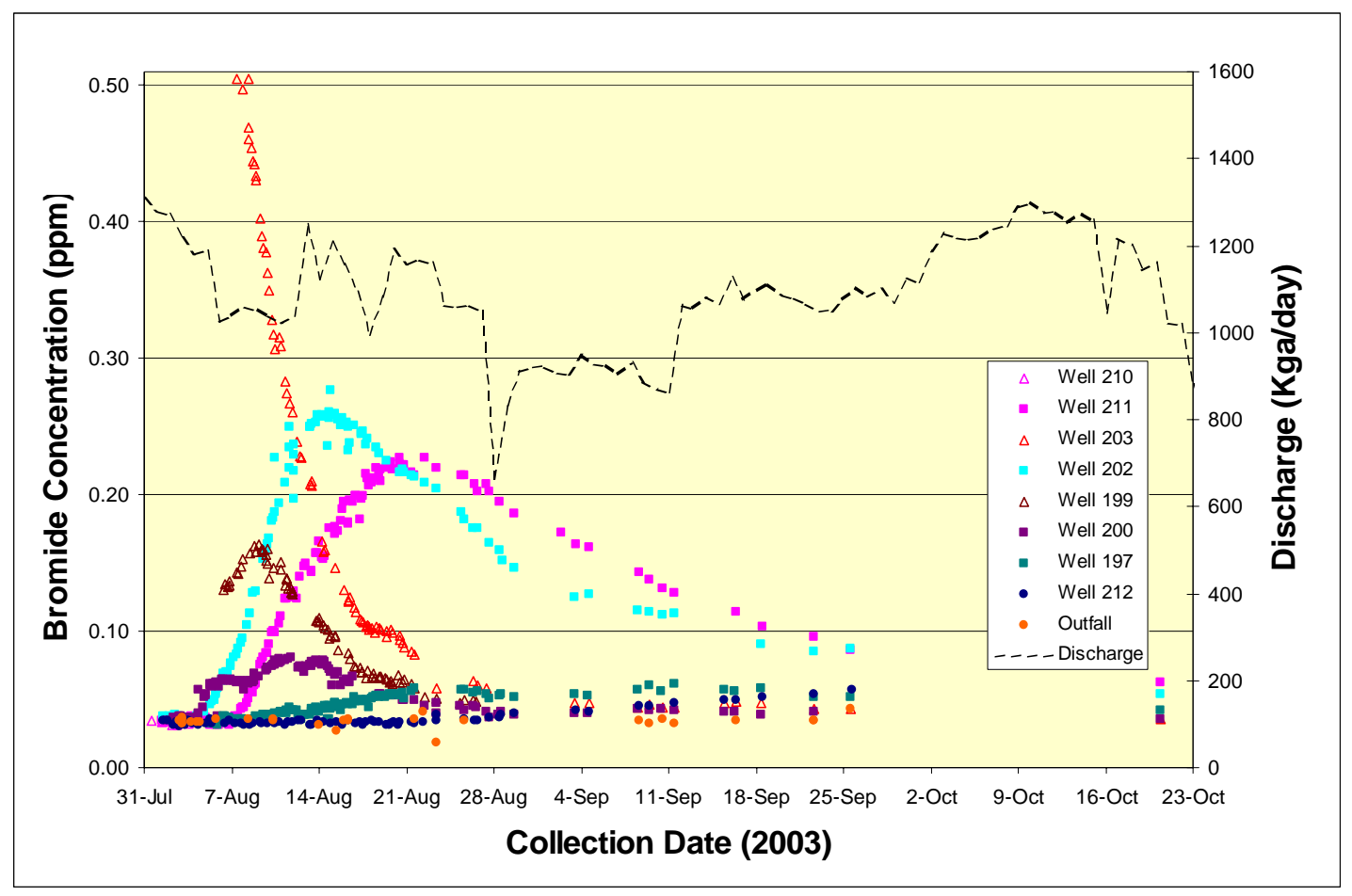

Figure 1. Recovery curves of $\mathrm{Br}^{-}$for all water-producing wells at the VZRP. Tracer was injected into the north pond on July 31, 2003 along with 2,4,-dFBA.

\section{Planned Activities}

Analysis of the many samples collected from earlier test will continue, with data management, processing and evaluation continuing along with the analyses. We plan to conduct additional tests later this year to evaluate the effects of water chemistry and flow transients on colloid transport. Laboratory experiments using rock collected from the VZRP subsurface aimed at examining natural geochemical properties that could affect groundwater transport parameters has begun and will continue for many months

Additionally, plans are underway to instrument both the north and south infiltration ponds with electrical conductivity probes in three locations to accurately characterize the infiltration rate both ponds. Each of the 3-4 locations in each pond will have EC probes at land surface, 5 feet bls and 10 feet bls. We will be able to track infiltration rates out of the bottom of the pond by utilize the twice-daily spikes in EC due to water softener recharge events. These EC pulses will then be traced at they move from the surface into the shallow vadose zone. 


\section{Hydraulic Data Collection}

In addition to the tracer and geochemical tests, continuous hydrological data have been collected and analyzed since discharge to the pond began in October 2002. These data indicate a high degree of spatial variability within the shallow subsurface, resulting in directional flow that that changes with time (figure 2). Water arrival was observed at deeper locations before shallower ones, and lateral transport was observed not only at basalt /interbed interfaces but also within thick basalt layers. Recharge was observed as deep as $87-\mathrm{m}$ bls and as far away as the Big Lost River $860-\mathrm{m}$ to the north. New perched zones formed at the first alluvium/basalt interface on the southern end of the pond after discharge began to the south cell and at deeper lithologic interfaces where monitoring wells were completed on the northern, southern, and western perimeter of the pond. Preferential flow was found to be the most prevalent type of flow at the Vadose Zone Research Park, in contrast to the current INEEL conceptual model of vadose zone transport that adopts the diffuse flow model for contaminant transport predictions

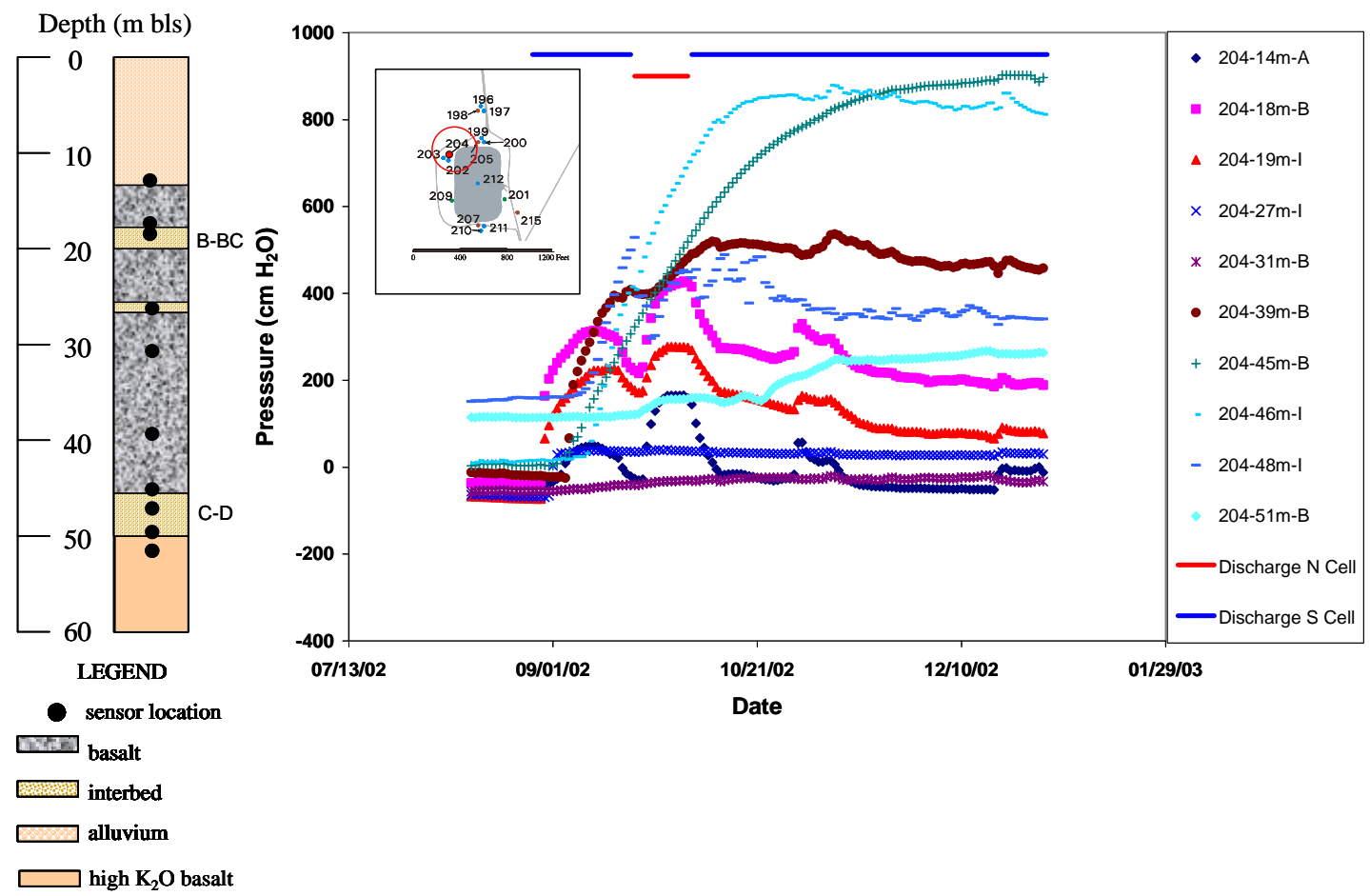

Figure 2. Well 204 tensiometer responses to initial water arrival and changes in discharge location for the months of August through October 2002. Pressure spikes in early November reflect a rapid increase in discharge volume, which lasted about 4 days. Tensiometers in this well were pulled for calibration December 19, 2002, also showing a spike in pressure.

\section{Information Access}

R. Roback presented an overview talk at the EMSP PI workshop at PNNL in May. LANL and INEEL project personnel presented abstracts at the 2003 annual AGU meeting in San Francisco (see this site for poster presentations).

Baker K, Hull, L.C. Bennett, J., Ansely S., Heath, G., Conceptual Models of Flow through a Heterogeneous, Layered Vadose Zone under a Percolation Pond (2004), Idaho National Engineering and Environmental Laboratory report INEEL/EXT-04-01679 (also posted). 